\title{
Pengaruh Model Pembelajaran Berbasis Masalah (PBM) Menggunakan Bahan Ajar Berbasis E-Materi Terhadap Pemahaman Konsep Fisika Pada Siswa Kelas X SMA N 1 Biromaru
}

\author{
Khaerul Hidayat, Amiruddin Kade dan Haeruddin \\ email : Rullbysan032@gmail.com \\ Program Studi Pendidikan Fisika FKIP Universitas Tadulako \\ Jl. Soekarno Hatta Km. 9 Kampus Bumi Tadulako Tondo Palu - Sulawesi Tengah
}

\begin{abstract}
Abstrak - Penelitian ini bertujuan untuk mengetahui pengaruh model pembelajaran berbasis masalah menggunakan bahan ajar berbasis e-materi terhadap pemahaman konsep fisika siswa kelas X SMAN 1 Biromaru. Penelitian ini menggunakan bahan ajar e-materi. Desain penelitian yang digunakan adalah The Non Equivalen Pretest-Posttest Design. Populasi penelitian ini adalah seluruh siswa kelas X pada SMAN 1 Biromaru, pengambilan sampel dilakukan secara purposive sampling, diperoleh sampel pada penelitian ini yaitu kelas $X$ Model1 sebagai kelas eksperimen dan Kelas X Model2 sebagai kelas kontrol. Instrumen yang digunakan pada penelitian ini adalah tes pemahaman konsep. Analisis data dilakukan dengan menggunakan program SPSS (Statical Product and Service Solution). Pengujian hipotesis didasarkan pada uji statistik yaitu Uji t untuk dua sampel independen dengan taraf signifikansi $(a=0,05)$. Kriteria yang digunakan yaitu jika signifikansi $>0,05$ maka hipotesis $1(\mathrm{H} 0)$ diterima dan hipotesis 2 ( $\mathrm{H} 1)$ ditolak sehingga dapat disimpulkan bahwa tidak terdapat perbedaan pemahaman konsep fisika antara kelas yang diajar dengan model pembelajaran berbasis masalah menggunakan bahan ajar berbasis e-materi dan kelas yang diajar dengan model pembelajaran langsung menggunakan bahan ajar berbasis e-materi atau sebaliknya jika signifikansi < 0,05. Berdasarkan hasil pengujian hipotesis posttest kelas kontrol dan ekperimen diperoleh signifikasi = 0,019 atau < 0,05. Dengan demikian $\mathrm{HO}$ ditolak atau H1 diterima. Sehingga dapat disimpulkan bahwa terdapat perbedaan yang signifikan antara pemahaman konsep fisika kelas yang menggunakan model pembelajaran berbasis masalah dan kelas yang menggunakan model pembelajaran langsung.
\end{abstract}

Kata Kunci: Pemahaman Konsep, Pembelajaran Berbasis Masalah, E-materi

\section{PENDAHULUAN}

Seiring dengan perkembangan ilmu pengetahuan dan teknologi pada saat ini, peningkatan kualitas siswa di bidang sains merupakan suatu tuntutan. Fisika sebagai salah satu bidang ilmu yang tergolong dalam bidang sains tidak terlepas dari tuntutan tersebut. Tuntutan ini ditujukan kepada siswa, namun yang menjadi kunci keberhasilannya adalah guru di sekolah. Untuk memenuhi tuntutan tersebut tidaklah mudah, dimana guru di hadapkan pada berbagai masalah. Salah satu masalah tersebut adalah anggapan siswa bahwa fisika sebagai pelajaran yang cukup sulit untuk dimengerti. Hal ini menjadi tugas guru untuk meyakinkan siswa bahwa pelajaran fisika tidaklah sesulit yang mereka pikirkan. Tentunya hal ini tidaklah mudah, melainkan membutuhkan kerja keras dan kesabaran.

Saat ini sudah menjadi budaya bahwa kegiatan belajar-mengajar di kelas kebanyakan berpusat pada guru. Dimana guru yang lebih aktif dalam kelas sementara siswa lebih pasif. $\mathrm{Hal}$ ini dikarenakan kebanyakan guru hanya memikirkan bagaimana agar materi yang diajarkan dapat diselesaikan tepat waktu tanpa memperhatikan apakah siswa mengerti atau tidak, sehingga ketika kegiatan belajarmengajar berlangsung siswa hanya sekedar mencatat konsep dan menghafal konsep. Akibatnya siswa kurang memahami konsep yang telah mereka pelajari yang berdampak pada rendahnya hasil belajar siswa. Begitu pentingnya pemahaman dalam proses pembelajaran sehingga Santyasa [1] menyatakan bahwa pemahaman (understanding) merupakan kata kunci dalam pembelajaran. Selain Referensi Sakti [2] juga menyatakan pemahaman adalah prasyarat mutlak untuk tingkatan kemapuan kognitif yang tinggi, aplikasi, analisis, sintesis, dan evaluasi.

Pemahaman merupakan suatu bentuk pengertian yang menyebabkan seseorang mengetahui apa yang sedang dikomonikasikan, dan dapat menggunakan bahan atau ide yang 
sedang dikomonikasikan itu tanpa harus menghubungkannya dengan bahan lain. Dalam kamus bahasa Indonesia pemahaman berasal dari kata paham yang artinya mengerti benar atau tahu benar, sehingga pemahaman diartikan sebagai proses, perbuatan, cara untuk mengerti benar atau mengetahui benar. Konsep adalah suatu ide, pikiran atau pengertian yang dibahasakan dari peristiwa nyata. Dalam kamus bahasa Indonesia konsep diartikan sebagai rancangan. Konsep merupakan bayangan mental dan proses. Suatu konsep memiliki suatu organisasi kognitif yang berguna untuk memecahkan masalah baru yang ditemukan. Sehingga dapat disimpulkan bahwa pemahaman konsep fisika adalah pemahaman konsep fisika adalah kemampuan siswa untuk mengetahui, mendefenisikan dan membahasakan sendiri konsep fisika yang telah dipelajarinya tanpa mengurangi maknanya

Untuk memudahkan siswa dalam memahami konsep maka seharusnya pembelajaran yang dihadapkan kepada siswa adalah pembelajaran yang menghadapkan siswa pada masalah-masalah di kehidupan sehari-hari siswa, sehingga pembelajaran siswa lebih bermakna. Peserta didik cepat lupa jika hanya dijelaskan secara lisan, mereka ingat jika diberikan contoh, dan memahami jika diberikan kesempatan mencoba memecahkan masalah [1]. Salah satu model pembelajaran yang dapat memberikan contoh ataupun masalah fisika yang berkaitan dengan kehidupan sehari-hari siswa adalah Model Pembelajaran Berbasis Masalah (PBM).

Pembelajaran berbasis masalah (PBM) melibatkan siswa dalam penyelidikan pilihan sendiri yang memungkinkan mereka menginterpretasikan dan menjelaskan fenomena dunia nyata dan membangun pemahaman tentang fenomena itu [3]. Pembelajaran berbasis masalah (PBM) merupakan pendekatan pembelajaran yang memberi kesempatan kepada siswa menyelidiki dan mempelajari situasi-situasi masalah otentik dan bermakna [4]. Dalam model ini proses pembelajaran siswa dihadapkan kepada masalah kehidupan nyata, sehingga siswa mampu memahami bagaimana konsep fisika itu.

Keberhasilan model pembelajaran berbasis masalah dapat dilihat pada penelitian sebelumnya yang dilakukan oleh Malik di SMAN 1 Marawola yang melihat pengaruh model pembelajaran berbasis masalah pada kemampuan berpikir kritis siswa. Selain itu menurut referensi [4] juga melakukan penelitian di pendidikan tinggi yaitu di pendidikan kesehatan dan menunjukkan keberhasilan model pembelajaran berbasis masalah.

Selain model pembelajaran terdapat juga berbagai macam perangkat pembelajaran yang dibuat seiring dengan kemajuan teknologi yaitu menggunakan media elektronik. Perangkat pembelajaran ini dirancang untuk memberikan kemudahan kepada guru dalam mengajar di kelas. Selain itu siswa juga akan memperoleh pembelajaran yang menarik dan menyenangkan. Menurut Referensi [5] Pembelajaran dengan menggunakan aplikasi komputer memberikan kesempatan kepada peserta didik untuk belajar secara dinamis dan interaktif. Salah satu perangkat pembelajaran yang dapat digunakan dalam proses belajar mengajar adalah perangkat pembelajaran berbasis e-materi yang menggunakan software exe. Sebagaimana Warjana [6] mengatakan bahwa salah satu aplikasi yang dapat digunakan untuk membuat bahan ajar adalah exe.

E-materi merupakan seperangkat informasi bidang ilmu yang terstruktur untuk pembelajaran yang disajikan dalam bentuk elektronik. Perangkat pembelajaran e-materi dapat ditampilkan di dalam kelas dengan menggunakan projektor. Dengan adanya perangkat pembelajaran berbasis e-materi siswa dapat belajar dengan menyenangkan dan lebih mudah memahami pelajaran karena siswa akan memperoleh pelajaran dalam bentuk informasi (textual, gambar, audio, video, simulasi maupun multimedia). E-materi dapat berupa aset-aset yang terpisah dan disusun secara bermakna sehingga dapat diakses untuk memperkaya penjelasan agar pembelajaran lebih memahami bagian yang diterangkan dalam sebuah buku ajar [7].

Exe merupakan singkatan dari elearning XHTML editor. Exe adalah sebuah aplikasi gratis kode terbuka yang bisa digunakan membuat content web tanpa harus mengetahui bahasa pemprograman HTML. Exe merupakan aplikasi open source serta gratis dalam pembuatan bahan ajar berbasis web [6] Program exe dapat menyajikan gambar, suara, video maupun simulasi sehingga lebih mudah dipahami. Exe ini sangat cocok digunakan sebagai software emateri karena exe dapat diunduh dengan mudah dan gratis. Hal ini didukung oleh pernyataan bahwa perangkat lunak yang digunakan seharusnya berupa perangkat yang 
sudah umum digunakan oleh orang pada umumnya dan bebas diunduh tanpa biaya [7].

Berdasarkan paparan di atas penulis tertarik untuk melakukan suatu penelitian tentang "Pengaruh Model Pembelajaran Berbasis Masalah (PBM) Menggunakan Bahan Ajar Berbasis E-materi Terhadap Pemahaman Konsep Fisika pada Siswa kelas X SMAN 1 Biromaru".

Dalam pelaksanaan penelitian ini, peneliti menggunakan model pembelajaran langsung sebagai variabel kontrol, karena model pembelajaran langsung merupakan model pembelajaran yang sudah lazim digunakan di sekolah. Model pembelajaran langsung (direct instruction) merupakan model pembelajaran yang pembelajarannya berpusat pada guru. Dalam model ini guru mendemontrasikan materi pembelajaran tahap demi tahap. Model pembelajaran langsung dirancang secara khusus untuk mengembangkan belajar siswa tentang pengetahuan procedural dan pengetahuan deklaratif yang terstruktur dengan baik dan dapat dipelajari selangkah demi selangkah Lanang [8].

\section{METODOLOGI PENELITIAN}

Penelitian ini menggunakan metode eksperimen Kuasi, dengan desain penelitian"The non ekivalen pretest-postest design" atau desain kelompok pembanding posttest. Adapun desain penelitian tersebut adalah seperti pada Tabel 1:

Tabel 1: Desain Penelitian : The non ekivalen pretestpostest design

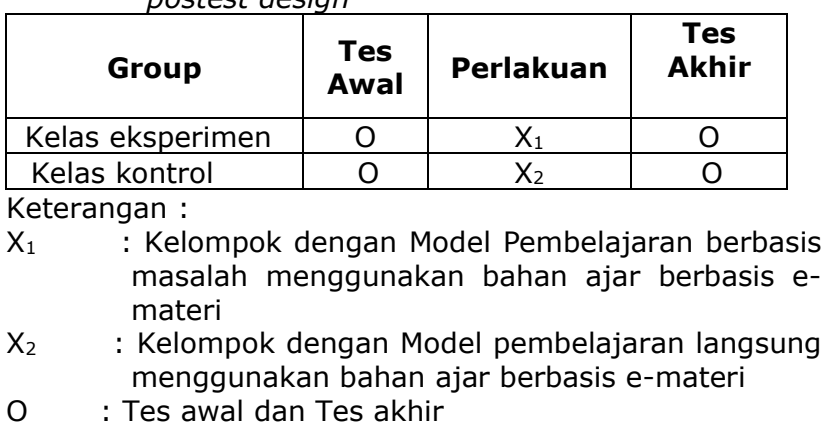

\section{Populasi, Sampel dan Teknik Pengambi- Ian Sampel}

Adapun populasi dari penelitian ini adalah seluruh siswa kelas $X$ di SMAN 1 Biromaru. Sedangkan yang menjadi Sampel atau subjek penelitian ini adalah seluruh siswa kelas X Mod- el1 dan $X$ Model2. Pengambilan sampel dilakukan dengan menggunakan teknik penentuan sampel dengan pertimbangan tertentu (Purposive Sampling) yaitu dengan melihat nilai ratarata kelas yang relative sama dalam prestasi belajar fisika. Sampel ditentukan berdasarkan rekomendasi guru. Kelas X Model 1 sebagai kelas eksperimen dan kelas $X$ Model 2 sebagai kelas kontrol.

\section{Jenis dan Sumber Data}

Jenis data penelitian mencakup data primer yang bersumber langsung dari siswa dan data sekunder yang bersumber dari guru fisika yang di sekolah SMAN 1 Biromaru.

\section{Teknik pengumpulan data}

Tehnik pengumpulan data dalam penelitian meliputi 3 tahap yaitu :

1. Tahap persiapan

a. Menentukan lokasi penelitian

b. Menentukan populasi dan sampel penelitian

c. Menyusun instrumen yang akan digunakan dalam penelitian

d. Melakukan validitas tes.

e. Penentuan kelas eksperimen dan kelas kontrol yang ditentukan oleh peneliti di SMA Negeri 1 Biromaru.

2. Tahap pelaksanaan

a. Pemberian tes awal (Pretest)

Dalam hal ini siswa di kelas eksperimen dan control diberikan soal-soal yang sama dan telah divalidasi oleh validator, guna mengetahui kemampuan awal siswa.

b. Pemberian perlakuan

Proses belajar mengajar dilakukan dengan memberikan perlakuan berupa pengajaran dengan menerapkan pembelajaran berbasis masalah dengan menggunakan bahan ajar e-materi. Pada model ini menghadapkan siswa pada masalahmasalah dikehidupan sehari-hari siswa melalui penjelasan dan video animasi yang terdapat dalam bahan ajar e-materi untuk memunculkan ide-ide siswa. Dari sini siswa dapat membuat jawaban sementara yang selanjutnya diuji dengan mencocokkannya dengan pendapat para ahli atau teori yang sebenarnya.

c. Pemberian tes akhir

Dalam pemberian test akhir (posttest) dilakukan pada dua kelas yaitu kelas eksperimen dan kelas control. Tes akhir ini 
ISSN 23383240

akan di berikan setelah berakhirnya proses belajar mengajar yang bertujuan untuk mendapatkan perbedaan nilai hasil belajar yang dialami siswa.

3. Tahap Akhir

Kegiatan yang akan dilakukan pada tahap ini adalah tabulasi data, pengolahan data, menganalisis data sampel dan menarik kesimpulan pada laporan hasil penelitian.

\section{a. Uji normalitas}

\section{Analisis data hasil penelitian}

Dalam penelitian ini pengujian Normalitas dilakukan dengan menggunakan program SPSS (Statical Product and Service Solution). Pengujian normalitas dilakukan untuk melihat apakah data yang diperoleh dari hasil penelitian berdistribusi normal atau tidak. Data yang dimaksud adalah nilai pemahaman konsep siswa yang diperoleh dari siswa kelompok eksperimen dan kelompok kontrol. Uji ini didasarkan pada uji statistik yaitu Uji Chi-kuadrat. Kriteria yang digunakan yaitu jika signifikansi < 0,05, maka data tidak berdistribusi normal. Sebaliknya, jika signifikansi $>0,05$, maka data berdistribusi normal Priyatno [9].

\section{b. Uji homogenitas}

Pada penelitian ini pengujian dilakukan dengan menggunakan program SPSS (Statical Product and Service Solution). Untuk menguji homogenitas varians data tes pemahaman konsep antara kelas eksperimen dan kelas kontrol menggunakan uji $t$ untuk dua sampel independen. Uji homogenitas varians digunakan untuk mengetahui apakah varians antara kedua kelas ekperimen sama atau berbeda. Dalam hal ini kelompok yang dimaksud adalah kelas ekperimen dan kelas kontrol. Pengujian homogenitas dilakukan pada taraf signifikansi (a $=0,05)$. Kriteria yang digunakan yaitu jika signifikansi $<0,05$, maka disimpulkan bahwa varian kelompok data adalah berbeda; sebaliknya, jika signifikansi > 0,05, maka disimpulkan bahwa varian kelompok data adalah sama [9].

\section{c. Uji hipotesis}

Untuk melihat seberapa jauh hipotesis yang telah dirumuskan didukung oleh data yang dikumpulkan, maka hipotesis tersebut harus diuji. Pengujian hipotesis ini dilakukan dengan menggunakan program SPSS (Statical Product and Service Solution). Uji ini didasarkan pada uji statistik yaitu uji $t$ untuk dua sampel independen yang pada prinsipnya akan membandingkan rata-rata dari dua grup yang tidak berhubungan satu dengan yang lain, dengan tujuan apakah kedua grup tersebut mempunyai rata-rata yang sama ataukah tidak secara signifikan. Pengujian hipotesis dilakukan pada taraf signifikansi $(a=0,05)$. Kriteria yang digunakan yaitu jika signifikansi $>0,05$, maka disimpulkan bahwa hipotesis 1 ( $\mathrm{HO}$ ) diterima atau hipotesis 2 ( $\mathrm{H} 1)$ ditolak. Jika signifikansi < 0,05, maka disimpulkan bahwa hipotesis $1(\mathrm{H} 0)$ ditolak atau hipotesis 2 (H1) dterima [9].

Dengan pasangan hipotesis adalah :

a. $\mathrm{HO}: \mu \mathrm{O}=\mu 1$ : Tidak terdapat perbedaan pemahaman konsep fisika antara kelas yang diajar dengan model pembelajaran berbasis masalah (PBM) menggunakan bahan ajar berbasis emateri dan kelas yang diajar dengan model pembelajaran langsung menggunakan bahan ajar berbasis emateri.

b. $\quad \mathrm{H} 1: \mu 0 \neq \mu 1$ : Terdapat perbedaan pemahaman konsep fisika antara kelas yang diajar dengan model pembelajaran berbasis masalah (PBM) menggunakan bahan ajar berbasis e-materi dan kelas yang diajar dengan model pembelajaran langsung menggunakan bahan ajar berbasis e-materi.

\section{HASIL DAN PEMBAHASAN}

\section{Hasil Belajar Fisika Siswa}

Data pemahaman konsep fisika siswa diperoleh dari hasil pretest dan posttest yang dilakukan pada kedua kelas tersebut. Adapun data hasil pemahaman konsep fisika siswa dapat dilihat pada Tabel 2:

Tabel 2.Skor Pretest dan Posstest kelas Eksperimen dan Kontrol

\begin{tabular}{|l|c|c|c|c|}
\hline \multirow{2}{*}{ Uraian } & \multicolumn{2}{|c|}{ Tes Awal } & \multicolumn{2}{c|}{ Tes Akhir } \\
\cline { 2 - 5 } & $\begin{array}{c}\text { Kelas } \\
\text { Eksperim } \\
\text { en }\end{array}$ & $\begin{array}{c}\text { Kelas } \\
\text { Kontrol }\end{array}$ & $\begin{array}{c}\text { Kelas } \\
\text { Eksperim } \\
\text { en }\end{array}$ & $\begin{array}{c}\text { Kelas } \\
\text { Kontrol }\end{array}$ \\
\hline Rata-rata & 16,14 & 15,83 & 63,64 & 56,43 \\
\hline Tertinggi & 25,00 & 25,00 & 80,00 & 77,50 \\
\hline Terendah & 5,00 & 5,00 & 45,00 & 35,00 \\
\hline
\end{tabular}

Dari Tabel 2 dapat dilihat bahwa terdapat perbedaan nilai pada kelas ekperimen yang menggunakan model pembelajaran ber- 


\section{Jurnal Pendidikan Fisika Tadulako (JPFT) \\ Vol. 1 No. 3}

ISSN 23383240

basis model dan kelas ekperimen yang menggunakan model pembelajaran langsung

\section{b. Hasil Uji Normalitas Data}

Untuk menguji data hasil test pemahaman konsep fisika tersebut terdistribusi normal atau tidak maka digunakan persamaan chi kuadrat. Pengujian dilakukan dengan menggunakan program SPSS (Statical Product and Service Solution). Data hasil pengujian normalitas dapat dilihat pada Tabel 3 dan 4 berikut:

\section{Uji Normalitas Tes Awal}

Tabel 3. Uji Normalitas pretest kelas kontrol dan kelas eksperimen

Tests of Normality

\begin{tabular}{|c|c|c|c|}
\hline & \multirow[t]{2}{*}{ Kelas } & \multicolumn{2}{|c|}{ Shapiro-Wilk } \\
\hline & & Df & Sig. \\
\hline Tes_Pemahaman_ & kelas eksperimen & 22 & .104 \\
\hline Konsep & kelas control & 21 & .392 \\
\hline
\end{tabular}

Tabel 4. Uji Normalitas posttest kelas kontrol dan kelas eksperimen

Tests of Normality

\begin{tabular}{|c|c|c|c|}
\hline \multirow{2}{*}{\multicolumn{2}{|c|}{ Kelas }} & \multicolumn{2}{|c|}{ Shapiro-Wilk } \\
\hline & & Df & Sig. \\
\hline Tes_Pemahaman_ & kelas eksperimen & 22 & .757 \\
\hline Konsep & kelas control & 21 & .601 \\
\hline
\end{tabular}

Pada data uji normalitas pretest untuk kelas eksperimen memiliki signifikan $=0,104$ dan pada kelas kontrol sig. $=0,392$. Kedua kelas memiliki sig. $>0,05$, oleh karena itu data terdistribusi normal. Pada data uji normalitas posttest kelas eksperimen memiliki sig. $=0,757$ dan pada kelas kontrol sig. $=0,601$. Kedua kelas memiliki sig. $>0,05$, oleh karena itu data terdistribusi normal.

\section{c. Uji Homogenitas Varians Data}

Untuk menguji homogenitas varians data tes pemahaman konsep antara kelas eksperimen dan kelas kontrol menggunakan uji t untuk dua sampel independen. Pengujian dilakukan dengan menggunakan program SPSS (Statical
Product and Service Solution). Data hasil pengujian homogenitas dapat dilihat pada Tabel 5 dan 6:

Tabel 5. Uji Homogenitas pretest kelas kontrol dan kelas eksperimen

Independent Samples Test

\begin{tabular}{|cl|c|c|}
\hline \multirow{2}{*}{} & \multicolumn{2}{|c|}{$\begin{array}{c}\text { Levene's Test for } \\
\text { Equality of } \\
\text { Variances }\end{array}$} \\
\cline { 3 - 4 } & $\mathrm{F}$ & Sig. \\
\hline $\begin{array}{l}\text { Nilai_Pemaham } \\
\text { an_Konsep }\end{array}$ & $\begin{array}{l}\text { Equal variances } \\
\text { assumed } \\
\text { Equal variances } \\
\text { not assumed }\end{array}$ & 1,734 &, 195 \\
& & \\
\hline
\end{tabular}

Tabel 6. Uji Homogenitas Posttest kelas kontrol dan kelas eksperimen

Independent Samples Test

\begin{tabular}{|ll|c|c|}
\hline \multirow{2}{*}{} & \multicolumn{2}{|c|}{$\begin{array}{c}\text { Levene's Test } \\
\text { for Equality of } \\
\text { Variances }\end{array}$} \\
\cline { 2 - 4 } Nilai_Pemaha & $\begin{array}{l}\text { Equal variances } \\
\text { assumed } \\
\text { man_Konsep } \\
\text { Equal variances } \\
\text { not assumed }\end{array}$ & 1,904 & Sig. \\
\hline
\end{tabular}

Hasil uji homogenitas pretest kelas kontrol dan eksperimen menunjukkan sig. $=0,195$ dan pada posttest kelas kontrol dan eksperimen sig. $=0,175$. Hasil dari kedua data tersebut memiliki sig. $>0,05$, maka kedua varians kelompok data sama (homogen).

\section{d. Uji Hipotesis}

Pengujian uji hipotesis didasarkan pada uji statistik yaitu Uji t untuk dua sampel independen. Pengujian hipotesis ini dilakukan dengan menggunakan program SPSS (Statical Product and Service Solution). Data hasil pengujian hipotesis dapat dilihat pada Tabel 7 dan 8:

Tabel 7. Uji Hipotesis pretest kelas kontrol dan kelas eksperimen

Independent Samples Test

\begin{tabular}{|c|c|c|c|}
\hline & \multicolumn{3}{|c|}{$\begin{array}{l}\text { t-test for Equality of } \\
\text { Means }\end{array}$} \\
\hline & $t$ & $\mathrm{df}$ & $\begin{array}{l}\text { Sig. (2- } \\
\text { tailed) }\end{array}$ \\
\hline $\begin{array}{ll}\text { Nilai_Pema } & \text { Equal variances } \\
\text { haman_Ko } & \text { assumed } \\
& \text { Equal variances } \\
\text { nsep } & \text { not assumed }\end{array}$ & $\begin{array}{l}, 192 \\
, 192\end{array}$ & $\begin{array}{c}41 \\
40,734\end{array}$ & $\begin{array}{l}, 849 \\
, 848\end{array}$ \\
\hline
\end{tabular}


Tabel 8. Uji Hipotesis posttest kelas kontrol dan kelas eksperimen

Independent Samples Test

\begin{tabular}{|ll|c|c|c|}
\hline \multirow{2}{*}{} & \multicolumn{3}{|c|}{ t-test for Equality of Means } \\
\cline { 2 - 4 } & $\mathrm{t}$ & $\mathrm{df}$ & $\begin{array}{c}\text { Sig. (2- } \\
\text { tailed) }\end{array}$ \\
\hline $\begin{array}{l}\text { Nilai_Pem } \\
\text { ahaman_K } \\
\text { onsep }\end{array}$ & $\begin{array}{l}\text { Equal variances } \\
\text { assumed } \\
\text { Equal variances }\end{array}$ & 2,437 & 41 &, 019 \\
\hline
\end{tabular}

Hasil uji hipotesis pretest kelas kontrol dan eksperimen pada model pembelajaran menunjukkan sig. $=0,849$. Nilai sig. $>0,05$ maka HO diterima. Sehingga dapat disimpulkan bahwa tidak terdapat perbedaan pemahaman konsep fisika antara kelas kontrol dan kelas eksperimen.

Hasil uji hipotesis posttest kelas kontrol dan eksperimen pada model pembelajaran menunjukkan sig. $=0,019$. Nilai sig. $>0,05$ maka HO ditolak atau H1 diterima. Sehingga dapat disimpulkan bahwa terdapat perbedaan pemahaman konsep fisika antara kelas yang diajar dengan model pembelajaran berbasis masalah menggunakan bahan ajar e-materi dan kelas yang diajar dengan model pembelajaran langsung menggunakan bahan ajar e-materi.

Penelitian ini bertujuan untuk menguji signifikansi perbedaan pemahaman konsep fisika antara kelas eksperimen yang menggunakan model pembelajaran berbasis masalah dan kelas kontrol yang menggunakan model pembelajaran langsung. Sementara peran e-materi dalam penelitian ini sebagai bahan ajar yang digunakan pada kelas eksperimen dan kelas kontrol dengan tujuan untuk menciptakan pembelajaran yang lebih menarik lebih mudah dipahami.

Dalam penelitian ini, siswa kelas $X$ Model 1 sebagai kelas eksperimen dan kelas $X$ Model 2 sebagai kelas kontrol. Penelitin ini dilakukan sebanyak 5 kali pertemuan yang terdiri dari 1 kali pertemuan pretest, 3 kali tatap muka dan 1 kali pertemuan posttest. Pada kegiatan pretest peneliti memberikan tes pemahaman konsep untuk melihat. Pada kegiatan tatap muka peneliti memberikan perlakuan yang berbeda antara kelas eksperimen dan kelas kontrol yang tujuannya untuk meningkatkan pemahaman konsep siswa. Sementara pada kegiatan posttest peneliti memberikan tes yang sama dengan tes yang diberikan pada kegiatan pretest dengan tujuan untuk mengukur pemahaman konsep fisika yang diperoleh siswa pada saat kegiatan tatap muka.

Meningkatnya nilai pemahaman konsep kelas eksperimen pada posstest tentunya disebabkan oleh model pembelajaran yang digunakan pada kelas eksperimen yaitu model pembelajaran berbasis masalah dan adanya bahan ajar e-materi dalam model ini menciptakan pembelajaran yang lebih menyenangkan. Dalam penelitian ini model pembelajaran berbasis masalah ditandai oleh siswa yang bekerja berpasangan atau kelompok-kelompok kecil untuk menyelidiki masalah fisika. Tidak seperti model lainnya yang menekankan pada prestasi ide-ide dan pendemonstrasian keterampilanketerampilan, pembelajaran berbasis masalah menghendaki guru menyajikan situasi masalah kepada siswa dan membimbing siswa menyelidiki dan menemukan solusinya. Dalam penggunaannya model pembelajaran berbasis masalah memiliki 5 fase atau tahapan yaitu fase 1 adalah mengorientasikan siswa pada masalah, fase 2 adalah mengorganisasi siswa untuk belajar, fase 3 membantu penyelidikan mandiri dan kelompok, fase 4 adalah mengembangkan dan menyajikan hasil karya serta memamerkannya, dan fase 5 adalah menganalisis dan mengevaluasi proses pemecahan masalah. Pada fase 1 yaitu mengorientasikan siswa pada masalah. Pada fase ini guru mengimformasikan 


\section{Jurnal Pendidikan Fisika Tadulako (JPFT)}

Vol. 1 No. 3

ISSN 23383240

tujuan-tujuan pembelajaran yang ditampilkan dalam bahan ajar e-materi, menumbuhkan sikap positif terhadap tujuan pembelajaran tersebut dengan memberikan motivasi kepada siswa yaitu dengan memberikan pertanyaan kepada siswa misalnya pada pertemuan pertama "Apakah andi yang sedang duduk diam di kantin dapat dikatakan bergerak terhadap dewi yang sedang menuju ke kantin tempat andi duduk?". Dengan pertanyaan tersebut siswa akan menjawab "ya" atau "tidak" kemudian ditanggapi lagi oleh guru dengan meminta alasan siswa menjawab "ya" atau "tidak". Sehingga terjadi umpan balik antara guru dan siswa yang dapat meningkatkan rasa ingin tahu siswa terhadap materi pembelajaran. Pada pertemuan pertama dalam fase ini guru juga menjelaskan langkah-langkah model pembelajaran berbasis masalah secara rinci agar siswa mengetahui hal-hal yang harus mereka lakukan ketika pembelajaran berlangsung.

Pada fase 2 yaitu mengorganisasikan siswa untuk belajar. Pada fase ini guru membentuk siswa dalam kelompok yang merupakan inti dari pembelajaran berbasis masalah. Selanjutnya guru membagikan lembar kerja kelompok (LKK) yang memuat peristiwa-peristiwa dalam kehidupan sehari-hari yang didalamnya terdapat permasalahan fisika, namun sebelum menyelesaikan masalah tersebut siswa harus menemukan permasalahan fisika yang dalam LKK tersebut. Setelah itu guru membantu siswa dalam menemukan masalah-masalah yang ada dalam LKK dalam hal ini guru tidak secara langsung memberitahukan permasalahannya kepada siswa, melainkan membantu siswa yang masih kurang mengerti.

Fase 3 yaitu membantu penyelidikan mandiri dan kelompok. Tugas guru pada fase ini adalah mendorong siswa untuk mengumpulkan informasi untuk mencari penjelalasan dan solusi. Melalui fase ini guru seharusnya memberikan bantuan yang dibutuhkan tanpa terlalu mencampuri penyelidikan siswa. Dalam hal ini guru tetap menjaga jarak dan membiarkan siswa mengikuti arah dan inisiatif siswa itu sendiri. Setelah siswa cukup mengumpulkan informasi atas masalah yang sedang diselidiki, mereka dapat menawarkan penjelasan dalam bentuk hipotesis dan solusi. Selama fase pembelajaran cukup banyak siswa yang belum tahu cara membuat hipotesis terutama pada pertemuan pertama namun karena adanya bimbingan dari guru, sehingga pertemuan berikutnya siswa sudah mampu membuat hipotesis. namun demikian guru tetap merespon positif semua ide siswa dan menerima sepenuhya ide-ide tersebut.

Fase 4 yaitu mengembangkan dan menyajikan hasil karya serta memamerkannya. Pada fase ini masing-masing kelompok yang telah melakukan penyelidikan dan membuat hipotesis diminta oleh guru untuk menunjuk salah satu perwakilan untuk mempresentasikan hipotesis dan solusi yang mereka peroleh di depan kelas. Fase ini akan meningkatkan kepercayaan diri dari masing-masing kelompok akan kebenaran hipotesis yang mereka peroleh dibandingkan hipotesis kelompok lainnya.

Fase 5 yaitu menganalisis dan mengevaluasi proses pemecahan masalah. Pada fase ini guru membantu siswa mengevaluasi kembali hipotesis siswa dengan meminta masingmasing kelompok untuk mencocokkan hipotesis yang mereka buat dengan teori yang sebenarnya yang sudah disiapkan oleh guru dalam bahan ajar e-materi. Dengan demikian siswa dapat mengetahui jika terdapat kesalahan pada hipotesisnya dan akan berusaha memperbaiki agar sesuai dengan teori yang sebenarnya. Selanjutnya siswa yang masih kurang memahami dipersilahkan untuk menanyakan hal-hal yang belum dipahami yang berhubungan dengan materi yang sedang diajarkan.

Dari kelima fase tersebut, fase ke 3 merupakan fase yang paling berperan dalam peningkatan pemahaman siswa, karena pada fase ini siswa secara langsung menyelidiki permasalahan yang diberikan sehingga siswa memperoleh pembelajaran yang lebih bermakna yang membuat siswa lebih mudah memahami konsep dari permasalahan-permasalahan yang ada.

Jika ditinjau secara umum, penggunaan model pembelajaran berbasis masalah lebih efektif dalam proses belajar mengajar karena dengan model ini siswa menjadi lebih aktif dalam proses pembelajaran yang menyebabkan siswa lebih mudah mengingat konsep-konsep yang 
mereka temukan sendiri pada saat proses menemukan dan memecahkan masalah. Berdasarkan paparan tersebut, untuk mendukung keberhasilan penelitian ini dapat dibandingkan dengan penelitian yang dilakukan oleh Juliawan [10] yang meneliti tentang pengaruh model pembelajaran berbasis masalah terhadap pemahaman konsep dan keterampilan proses sains siswa pada kelas XI IPA SMA Negeri 2 Kuta dan hasilnya menunjukkan bahwa terdapat pengaruh yang signifikan terhadap variabelvariabel pemahaman konsep dan keterampilan proses sains. Hasil penelitian Kharida [11] yang meneliti tentang penerapan model pembelajaran berbasis masalah untuk meningkatkan hasil belajar siswa pada pokok bahasan elastisitas bahan menunjukkan bahwa penerapan model pembelajaran berbasis masalah dapat meningkatkan aktivitas belajar dan hasil belajar siswa. Ini menunjukkan bahwa siswa yang diajar dengan model pembelajaran berbasis masalah lebih aktif dalam kelas dan hasil belajar siswa lebih baik.

Pada penggunaan model pembelajaran langsung yang menggunakan bahan ajar berbasis e-materi pada kelas kontrol guru memilih metode ceramah. Secara umum langkahlangkah yang dilakukan guru dalam model ini adalah menjelaskan materi yang ada pada bahan ajar e-materi, memberikan contoh soal kemudian memberikan soal latihan. Setelah semua itu dilakukan guru berharap siswa sudah mengerti dengan apa yang telah dijelaskan guru. Namun ketika guru memberikan pertanyaan kepada siswa, mereka lebih cenderung diam dan begitu guru meminta siswa menanyakan apa yang mereka belum mengerti, mereka juga cenderung diam. Hal ini mungkin disebabkan mereka takut kepada guru ataupun malu kepada temannya ketika mereka salah menjawab ataupun bertanya. Hal inilah yang membuat peneliti menarik suatu kesimpulan bahwa penggunaan model pembelajaran ini kurang efektif digunakan dalam proses pembelajaran yang dikarenakan dalam proses pembelajaran ini guru lebih aktif sementara siswa lebih pasif sehingga pembelajaran berpusat pada guru. Akibatnya siswa yang pada dasarnya takut dan malu bertanya pada guru selalu menjadi siswa yang pasif. Tentunya hal ini akan berdampak pada prestasi belajar siswa yang menjadi lebih menurun.

ISSN 23383240

IV. KESIMPULAN DAN SARAN

Berdasarkan hasil penelitian dapat disimpulkan bahwa terdapat perbedaan pemahaman konsep fisika antara kelompok siswa yang diajar dengan model pembelajaran berbasis masalah menggunakan bahan ajar e-materi dengan kelompok siswa yang mengikuti model pembelajaran langsung menggunakan bahan ajar e-materi. Hal tersebut dapat dilihat dari uji statistik data posttest yang menunjukkan terdapat perbedaan yang signifikan antara kelas eksperimen dengan kelas kontrol.

\section{Saran}

Berdasarkan pengalaman-pengalaman yang diperoleh selama penelitian maka penulis mengutarakan beberapa saran sebagai ide-ide untuk perbaikan penelitian dimasa mendatang.

1) Bahan ajar e-materi sebaiknya disesuaikan dengan model pembelajaran berbasis masalah.

2) Sebaiknya jika ada yang ingin meneliti model pembelajaran berbasis masalah, lakukanlah penelitian pada materi yang berbeda.

3) Penggunaan e-materi sebagai bahan ajar menciptakan pembelajaran yang lebih menarik dan menyenangkan

\section{DAFTAR RUJUKAN}

[1] Santyasa, I W. 2008. Pengembangan Pemahaman Konsep dan Kemampuan Pemecahan Masalah Fisika Bagi Siswa SMA dengan Pemberdayaan Model Perubahan Konseptual Berseting Investigasi Kelompok. Jurusan Pendidikan Fisika Universitas Pendidikan Ganesha. [online] Tersedia: http://www.freewebs.com/santyasa/pdf2/pengembang an_pemahaman_konsep.pdf. [diakses 03/01/2014]

[2] Sakti, I, dkk. 2012. Pengaruh Model Pembalajaran Langsung (Direct Instruction) Melalui Media Animasi Berbasis Macromedia Flash Terhadap Minat Belajar dan Pemahaman Konsep Fisika Siswa di SMA Plus Negeri 7 Kota Bengkulu. Jurnal Exacta Vol.X : 1-10. Fakultas Keguruan dan IImu Pendidikan Universitas Bengkulu. [online] Tersedia: http://repository.unib.ac.id-/487/ [diakses 03/01/2014].

[3] Rusman. 2011. Model-Model Pembelajaran. Bandung: Rajawali Pers.

[4] Nur, M. 2011. Model Pembelajaran Berdasarkan Masalah. Surabaya: Pusat Sains dan Matematika Sekolah UNESA.

[5] Rahman, R J. (2008). Optimalisasi Macromedia Flash Untuk Mendukung Pembelajaran Berbasis Komputer pada Program Studi IImu Komputer FPMIPA UPI. [online] tersedia: http://jurnal-teknologipendidikan.tp.ac.id/ [diakses 10/01/2013].

[6] Warjana, dkk. 2009. Membuat Bahan Ajar Berbasis WEB dengan EXE. Jakarta: PT Elex Media Komputindo. 


\section{Jurnal Pendidikan Fisika Tadulako (JPFT) \\ Vol. 1 No. 3}

ISSN 23383240

[7] Dikti. 2012. Pedoman Pengembangan E-Materi. [online] Tersedia: http://hibah-mpnk.dikti.go.id/ [diakses 18/12/2012].

[8] Lanang, I G. 2008. Penerapan Model Pembelajaran Langsung Berbantuan Media VCD Untuk Meningkatkan Aktivitas dan Hasil Belajar Mahasiswa Pada Perkuliahan Atletik I. Jurnal Penelitian dan Pengembangan Pendidikan Vol.II : 35-52. Jurusan Penjaskesrek FOK Undiksha Singaraja. www.freewebs.com/santyasa/Lemlit/PDF.../IGLA_Parw ata [diakses 03/01/2014].

[9] Priyatno, D. 2013. Analisis Korelasi, Regresi dan Multivariate dengan SPSS. Yogyakarta: Gava Media.

[10] Juliawan. 2011. Pengaruh Model Pembelajaran Berbasis Masalah Terhadap Pemahaman Konsep Dan Keterampilan Proses Sains Siswa pada Kelas XI IPA SMA Negeri 2 Kuta. Program Studi Pendidikan IPA. [online] Tersedia: http://pasca.undiksha.ac.id/ejournal/index.php/jurnal_ipa/article/download/400/19 2. diakses 03/08/2013].

[11] Kharida, dkk. 2009. Penerapan Model Pembelajaran Berbasis Masalah Untuk Peningkatan Hasil Belajar Siswa Pada Pokok Bahasan Elastisitas. Jurnal Pendidikan Fisika Indonesia Vol.V : 83-89. Jurusan Físika FMIPA Universitas Negeri Semarang. [online] Tersedia: http://journal.unnes.ac.id. [diakses 03/08/2013]. 